\title{
A GLOBALIZAÇÃO DO AGRONEGÓCIO E A DESTRUIÇÃO DO CAMPESINATO NO SÉCULO XXI.
}

\section{THE GLOBALIZATION OF AGRIBUSINESS AND THE DESTRUCTION OF THE PEASANTRY IN THE XXI CENTURY.}

\section{LA GLOBALIZACIÓN DE LO AGROCOMERCIO Y LA DESTRUCCIÓN DE LOS CAMPESINOS EN EL SIGLO XXI.}

\author{
Sérgio Gonçalves \\ Doutor em Geografia pela Unesp de Presidente Prudente-SP \\ Professor adjunto da Universidade Federal de Uberlândia - Campus de Ituiutaba/MG \\ Faculdade de Ciências Integradas do Pontal. Av. José João Dib, 2545 \\ Bairro Progresso. Ituiutaba - MG CEP 38 302-000 \\ sergiog@pontal.ufu.br
}

\begin{abstract}
Resumo
Este artigo faz um resgate do processo de formação e desenvolvimento do Agronegócio, focando a questão da industrialização da agricultura e da emergência da Agrobiotecnologia. Para tanto, desvenda os mecanismos de concentração, centralização e controle do capital sobre a agricultura, suas características principais. Além disso, trata do debate sobre o desenvolvimento da agricultura capitalista: a destruição do campesinato processada em escala global. Ademais, insere nesta discussão os aspectos atinentes à expansão da produção e da produtividade agrícola e da persistência da fome no mundo. Elabora, a partir disso, uma crítica ao Agronegócio e propõe a Agroecologia com fundamento necessário para redesenhar o atual sistema agrícola e alimentar com maneira de potencializar uma agricultura ambiental e socialmente desenvolvida.
\end{abstract}

Palavras-chave: Agronegócio, Destruição do Campesinato, Sistema Agrícola e Alimentar, Agroecologia.

\begin{abstract}
This article is a rescue of the formation and development process of Agribusiness. Focusing on the issue of agriculture's industrialization and the emergency of Agrobiotechnology, it unveils the mechanisms of concentration, centralization and capital control on agriculture, its main features, and it discusses about a central issue in the debate over capitalist agriculture development: the destruction of the peasantry processed on a global scale, inserting in this discussion the issue of production and agricultural productivity expansion and the persistence of world hunger. Engrossing a critique to Agribusiness, it proposes the Agroecology with necessary grounding to redesign the current agricultural and feeding system with a way to potentiate an agriculture environmentally and socially developed.
\end{abstract}

Keywords: Agribusiness, Peasantry Destruction, Agricultural and feeding System, Agroecology.

\section{Resumen}

Este documento hace el rescate de lo proceso de formación y desarrollo del 
Agrocomercio, tratando específicamente de la cuestión de la industrialización de la agricultura e de la emergencia de la Agrobiotecnología. Para tanto, desvenda los mecanismos de concentración, centralización y controle de lo capital sobre la agricultura, comentando sus características principales. Además, trata del debate sobre el desarrollo de la agricultura capitalista: la destruición de lo campesinato procesada en la escala global. Discute aún, los aspectos atinentes à expansión de la producción y da productividad agrícola e da persistencia del hambre en el mundo. Elabora una crítica sobre el Agrocomercio, y propone la Agroecología como fundamento necesario para cambiar el actual sistema agrícola y alimentario como manera de potencializar una agricultura ambiental y socialmente desarrollada.

Palavras-chave: Agrocomercio, Destruiccion del Campesinato, Sistema Agrícola y Alimentar, Agroecología.

\section{Introdução}

Este artigo faz um resgate do processo de formação e desenvolvimento do Agronegócio, abordando, assim, suas características principais. Além disso, trata de uma questão central no debate sobre o desenvolvimento da agricultura capitalista: a destruição do campesinato processada em escala global.

\section{O processo de industrialização da agricultura e o desenvolvimento da Agrobiotecnologia.}

Em meados do século XX, como consequência do atendimento aos ritmos e ditames de desenvolvimento do capitalismo industrial, um conjunto de ferramentas, inovações tecnológicas e lógicas organizacionais foram desenvolvidas e aplicadas no espaço agrário, provocando a integração da agricultura ao processo geral de industrialização.

Este desenvolvimento técnico-científico potencializou, por um lado, a capacidade de geração de riquezas no campo, sobretudo pelo aumento da produtividade e da produção de mercadorias agrícolas. Contudo, por outro lado, ampliou as "artimanhas" e as estratégias de drenagem da renda, produzida a partir do trato com a terra, realizadas pelos agentes do capital, já que parte considerável dos recursos econômicos dos produtores rurais passou a ser drenada e distribuída entre suas várias frações, quais sejam: o capital fundiário, o capital comercial, o capital financeiro e o capital agroindustrial; estruturados em diversas escalas de atuação e domínio 
(local/regional, nacional e internacional).

Este processo, inicialmente compreendido como industrialização da agricultura, foi teorizado e projetado por Lênin (1982) e Kautsky (1986) como inerente ao desenvolvimento capitalista da agricultura. Com efeito, tal processo é potencializador da diferenciação e da exclusão do campesinato, em virtude disso há, nesse ramo, presença constante de grandes produtores rurais, trabalhadores assalariados, organização de cadeias agroindustriais, fato que gera a exclusão social dos pequenos produtores considerados menos aptos.

Após 1950, a agricultura capitalista se desenvolveu com funções cada vez mais marginais e dependentes das empresas industriais e comerciais, do sistema bancário e das políticas públicas. Segundo Brum (1988), esta (inter)dependência setorial deveu-se às intensas modificações na base técnica da produção, a saber: a introdução crescente de elementos técnico-científicos (máquinas, implementos, equipamentos, insumos diversos, etc.) no processo produtivo; as mudanças nas relações sociais de produção (uma agricultura que visa o mercado e o lucro, portanto, a acumulação de capital); bem como a busca pela especialização produtiva (passagem dos policultivos para a monocultura).

Ademais, Brum (1988) também cita a organização de complexas cadeias de compra, armazenagem e beneficiamento da produção, além da expansão das políticas públicas, sobretudo a criação e a oferta de linhas de crédito para fomento da produção agropecuária. Houve, ainda, a organização do segmento da comercialização da produção, fato que propiciou o lastreamento do processo de industrialização da agricultura, tecnificação dos agricultores, assistência técnica rural, cooperativismo e modernização.

Para Elias (2003, p. 59), a industrialização da agricultura atingiu seu ápice nos anos 1980, quando diversas transformações impactaram as atividades agropecuárias em decorrência da revolução tecnológica. Nesse momento, a agricultura incorporou os principais signos e transformações pelos quais passaram os demais setores econômicoprodutivos. Desse modo, a emergência de novas formas de produção, de distribuição e de consumo determinaram a reestruturação da agricultura, que se organizou sob um novo modelo de desenvolvimento técnico, econômico e social. Cada vez mais moderna, a agricultura contemporânea seria aquela baseada 
[...] na incorporação da ciência, da tecnologia e da informação para aumentar a produção e a produtividade agropecuária, culminando com memoráveis transformações econômicas e, conseqüentemente, sócioespaciais. Hoje, também a agricultura se realiza de forma globalizada, se não na sua produção propriamente, mas na sua circulação, distribuição ou consumo, mostrando-se uma atividade das atividades mais contagiadas pela evolução tecnológica (ELIAS, 2003, p. 59).

O processo de produção agrícola se diversificou com o desenvolvimento das forças produtivas e dos novos aparatos tecnológicos disponibilizados para a prática da agricultura, além do conjunto de conhecimentos proporcionados pelo desenvolvimento da genética (produção de sementes melhoradas); da química e da bioquímica (produção de adubos, fertilizantes e agroquímicos); da técnica agropecuária (pedologia, zootecnia, medicina veterinária e agronomia); da mecânica (motorização e mecanização agrícola) e da biotecnologia (difusão das lavouras de organismos geneticamente modificados e a clonagem de plantas e animais). Estes, incorporados à agricultura, permitiram a difusão de artificialidades "criadoras" de ambientes favoráveis para a produção agrícola, como a drenagem de áreas alagadas, a irrigação de áreas desérticas, a plasticultura e a hidroponia (o cultivo de plantas na água, portanto, sem a necessidade de solo). Em virtude disso, houve o consequente aumento da produção e da produtividade.

A partir de 1990, com os avanços da clonagem de animais e das primeiras sementes transgênicas, desenvolveu-se a Agrobiotecnologia, padrão que se estrutura tecnicamente e se espacialisa mediante a incorporação e a aplicação deliberada de produtos oriundos da biotecnologia na agricultura e na pecuária.

O desenvolvimento da Agrobiotecnologia não é meramente uma mudança de cunho técnico aplicada no processo de produção, é resultado de uma intensa movimentação de capitais que visa à formação de mega-conglomerados no segmento da bioindústria. Em decorrência disso, há ampliação da capacidade de pesquisa e de inovação, bem como de oferta de produtos biotecnológicos, que são comprados e vendidos em um mercado regulado pelas patentes e direitos comerciais (royalties).

Segundo Capra (2005), uma das técnicas mais importantes para o desenvolvimento da biotecnologia é a engenharia genética, que contempla um conjunto de técnicas, como o isolamento, a modificação, a multiplicação e, sobretudo, a recombinação gênica. Essas técnicas permitem aos cientistas modularem a estrutura genética de organismos vivos, inserindo, em laboratório, genes específicos de outros 
organismos (ex: um gene que é responsável pela produção de uma toxina) na estrutura genética do organismo principal.

Entre as soluções, as inovações e os pacotes biotecnológicos destinados à agricultura e agroindústria, destacam-se as sementes transgênicas, a clonagem de animais e de plantas, as bactérias, bacilos, fermentos e microorganismos utilizados na produção de cervejas, vinhos, álcool, iogurtes, entre outras "mercadorias biológicas" que são as grandes vedetes da bioindústria para o desenvolvimento rural $\mathrm{e}$ agroindustrial.

Tecendo uma leitura geográfica sobre esta dinâmica, Santos (2002, p. 86) fala da existência de meio técnico-científico-informacional em seu processo de territorialização no campo, de maneira que, contemporaneamente, se vivencia no mundo a constituição de uma “[...] agricultura científica globalizada” (SANTOS, 2002, p. 88). Essa agricultura se ampara e depende cada vez mais nos auspícios da ciência, da técnica e da informação para garantir o aumento exponencial das quantidades produzidas em relação às superfícies plantadas, partilhando da lógica capitalista global de financeirização das relações, já que a agricultura passou a criar maior quantidade de produção, mobilizar e demandar maior quantidade de produtos, enfim, produzir e movimentar muito mais recursos financeiros.

Espacialmente, o processo de difusão da Agrobiotecnologia se assemelha à "Revolução Verde", à primeira etapa da agricultura industrial, pois se verifica a manutenção e a continuidade de vários aspectos a ela relacionados. Entre esses aspectos, cita-se: a produção de sementes de plantas direcionadas ao processamento agroindustrial (soja, milho, algodão, canola); o uso deliberado de insumos químicos para melhorar a produtividade dos solos e o controle das pragas e doenças; a existência de cadeias e circuitos produtivos ligados às articulações de diferentes frações do capital (comercial, industrial, bancário, fundiário); a presença das corporações transnacionais ofertando seus produtos; etc.

Porém, a substituição paradigmática que proporciona a superação da "Revolução Verde" e a ascensão da Agrobiotecnologia não se explica pelo estudo das formas que foram preservadas na agricultura espacializada, mas sim na análise das estruturas e dos processos espaciais, cuja transformação se dá pela atuação deliberada de segmentos dos agentes produtores do espaço geográfico, sobretudo, empresas e 


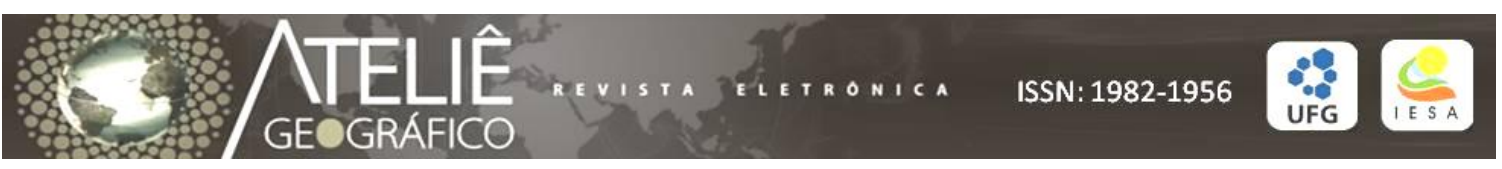

Estado. Esses agentes operam em favor da disseminação de produtos biotecnológicos na agricultura e redesenham o jogo de forças no campo e na cidade, determinando a estruturação do Agronegócio na escala global.

\section{Agronegócio: a expressão econômica do Capital oligopolizado na agricultura.}

O processo de desenvolvimento da "Revolução Verde" e da Agrobiotecnologia são produtos de um complexo processo de pluridimensionamento dos papéis da agricultura e suas relações e interconexões no sistema econômico, que são definidores de um sistema alimentar dinâmico globalmente interligado. Desse modo, a partir do momento em que as indústrias e as empresas comerciais passaram a se integrar de maneira mais sólida e a dominar os circuitos ligados à agricultura, gradualmente, estruturou-se o Agronegócio, cuja força e ímpeto permitem o controle e a definição sobre os rumos da agricultura mundial.

Com efeito, a expansão do Agronegócio é resultado direto da ação das transnacionais que lograram promover a complementaridade entre diferentes frações de capital e avançaram na estratégia internacional de aquisição de companhias para dominar os mercados e circuitos produtivos onde atuam.

Segundo Castro e Silveira (1985), esta estratégia iniciou com as empresas de sementes e de insumos. Grande parte das principais companhias do segmento da produção de sementes não operava somente neste setor, mas tinha suas estratégias de atuação em atividades correlatas, entre elas a química, a petroquímica (produção de adubos e pesticidas), além do segmento de processamento agroindustrial da produção.

Ademais, a sede destas companhias era localizada, geralmente, em nações desenvolvidas, como Inglaterra, Holanda, Suíça, Suécia, França, EUA e Alemanha. Atentos a esta estruturação, os governos destes países procuraram facilitar o processo, aprovando leis nacionais e negociando legislação e normas regulatórias em organismos internacionais para outorgar e garantir a essas corporações o controle de patentes sobre os cultivares que passaram a desenvolver - é claro que muitos deles foram "produzidos" a partir dos cultivares que cedidos "generosamente" dos bancos de germoplasma nacionais e internacionais. 
Por meio de táticas e estratégias diversas (aquisições de outras empresas, fusões, parcerias, aquisições de direitos de exploração, pagamento e cobrança de royaltyes, etc.), este processo de reestruturação visa reorganizar e remodelar a "indústria das ciências da vida" (“Life Sciences Industry”), sobretudo, as que tinham como carteira principal de produtos e serviços a produção e a venda de sementes agrícolas, agroquímicos, farmácia e a medicina animal.

Logo, comprar empresas concorrentes, vender mais, inovar em produtos e mercados, ampliar as estratégias de marketing e gerar dividendos são elementos específicos que orientam as relações econômicas e financeiras entre o capital produtivo e o capital especulativo. Segundo Santos (2002, p. 44), esta dinâmica do capital revela a tendência de "financeirização da economia mundial", com a perspectiva das finanças moverem a economia. Desse modo, essa intensa movimentação do capital internacional, buscando sua valorização, produz rebatimentos diretos na concentração corporativa nos setores da bioindústria, especialmente, aqueles que trabalham com a produção de sementes agrícolas, agroquímicos, fármacos e produtos da medicina animal (tabela 1).

Tabela 1: Participação Mundial das Multinacionais na Indústria Farmacêutica, Medicina Veterinária e Sementes 2004.

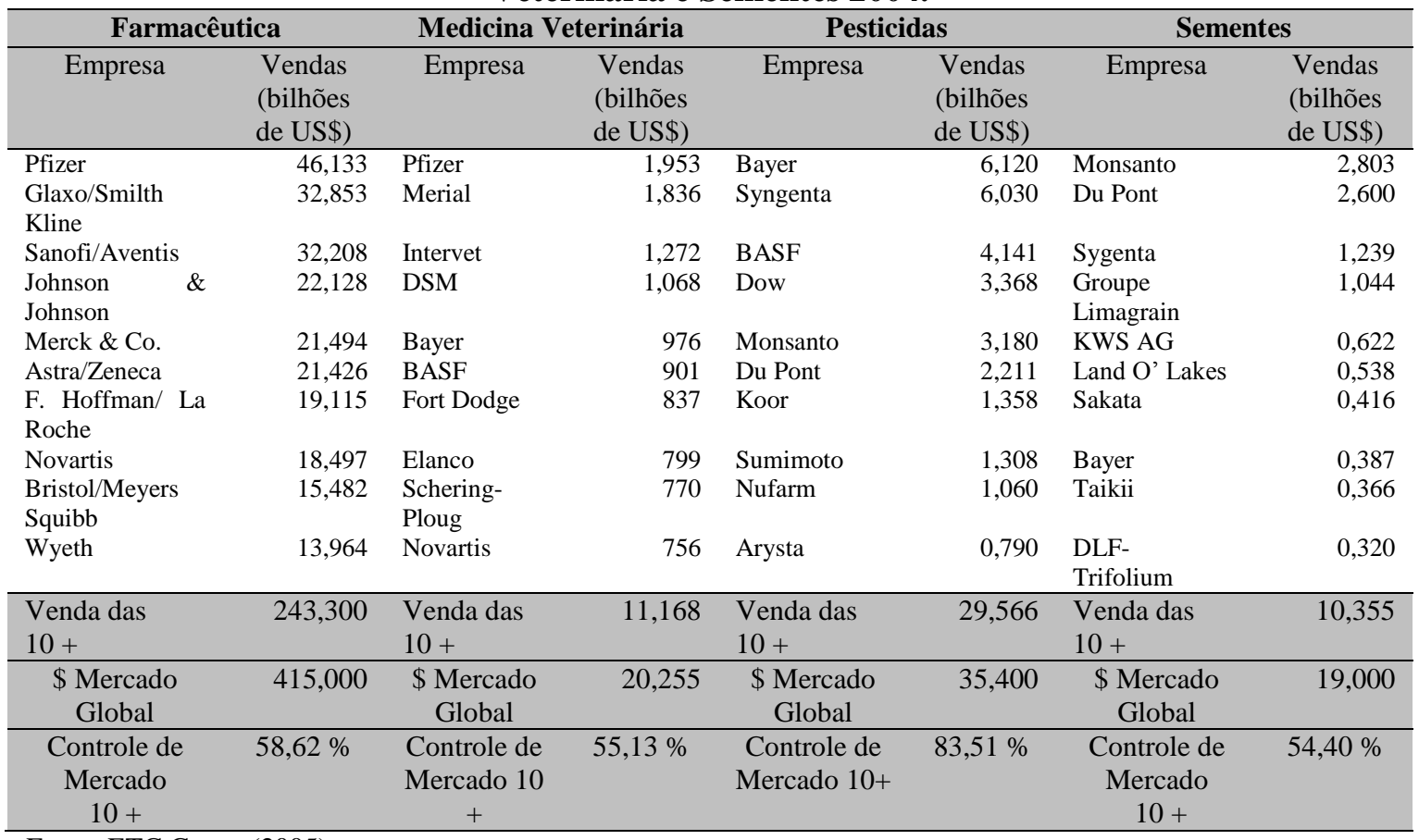

Fonte: ETC Group (2005). 
Os dados da tabela 1 permitem vislumbrar que a ação corporativa das dez principais empresas se faz mediante uma estratégia deliberada de controle mundial da maior fatia de mercado nos segmentos: da indústria farmacêutica (as 10 maiores empresas venderam, em 2004, 243,300 bilhões de dólares, cerca de 58,62\% do mercado mundial de fármacos); da indústria de produtos de medicina veterinária (movimentação de 11,168 bilhões de dólares ou 55,13\% das vendas do setor); da indústria de pesticidas (as vendas conjuntas de fungicidas, herbicidas e acaricidas pelas empresas supracitadas atingiram 29,566 bilhões de dólares, com o controle de $83,51 \%$ deste mercado) e da indústria de sementes agrícolas (as dez maiores empresas venderam 10,355 bilhões de dólares, obtendo 54,40\% das receitas do setor).

Nos setores de produção/comercialização/agroindustrialização/distribuição de alimentos e bebidas processados ou in natura (soja, milho, colza, algodão, açúcar, café, cacau, carnes, leite, trigo, arroz, frutas e verduras), além do segmento de supermercados; o domínio de mercado, a centralização e a concentração de capitais seguem a mesma tendência de oligopolização. Assim, as dez maiores "players" globais também mostram seus "músculos" (Tabela 2).

Tabela 2: Ranking Global das Empresas de Produção/Comercialização/ Agroindustrialização/Distribuição de Alimentos e Bebidas e Supermercados, 2004.

\begin{tabular}{|c|c|c|c|c|c|c|c|}
\hline \multicolumn{4}{|c|}{$\begin{array}{c}\text { Produção/Comercialização/Agroindustrialização/ } \\
\text { Distribuição de Alimentos e Bebidas } \\
\text { (milhão de dólares) }\end{array}$} & \multicolumn{4}{|c|}{$\begin{array}{l}\text { Supermercados } \\
\text { (milhão de dólares) }\end{array}$} \\
\hline Empresa & $\begin{array}{l}\text { Vendas } \\
\text { Totais } \\
\end{array}$ & $\%$ & Ranking & Empresa & $\begin{array}{l}\text { Vendas } \\
\text { Totais }\end{array}$ & $\%$ & Ranking \\
\hline Nestlé & 63,575 & $5,1 \%$ & $1^{\circ}$ & Wal-Mart & 287,989 & $8,2 \%$ & $1^{\circ}$ \\
\hline $\begin{array}{l}\text { ADM (Archer } \\
\text { Daniels Midland) }\end{array}$ & 35,944 & $3,1 \%$ & $2^{\circ}$ & Carrefour & 99,119 & $2,8 \%$ & $2^{\circ}$ \\
\hline Altria Group & 32,168 & $2,5 \%$ & $3^{\circ}$ & Metro AG & 76,942 & $2,1 \%$ & $3^{\circ}$ \\
\hline PesiCo & 29,261 & $2,3 \%$ & $4^{\circ}$ & Ahold & 70,439 & $2 \%$ & $4^{\circ}$ \\
\hline Unilever & 29,205 & $2,3 \%$ & $5^{\circ}$ & Tesco & 65,175 & $1,9 \%$ & $5^{\circ}$ \\
\hline Tyson Foods & 26,441 & $2,1 \%$ & $6^{\circ}$ & Kroger & 56,434 & $1,6 \%$ & $6^{\circ}$ \\
\hline Cargill & 24,000 & $1,9 \%$ & $7^{\circ}$ & Costco & 52,935 & $1,5 \%$ & $7^{\circ}$ \\
\hline Coca-Cola & 21,962 & $1,7 \%$ & $8^{\circ}$ & ITM Interprises & 51,800 & $1,4 \%$ & $8^{\circ}$ \\
\hline Mars. Inc. & 18,000 & $1,4 \%$ & $9^{\circ}$ & Albertson's & 39,897 & $1,1 \%$ & $9^{\circ}$ \\
\hline Danone & 17,040 & $1,3 \%$ & $10^{\circ}$ & Edeka Zentrale & 39,100 & $1,1 \%$ & $10^{\circ}$ \\
\hline $\begin{array}{l}\text { Venda das } \\
10+\end{array}$ & 297,596 & $23,81 \%$ & - & $\begin{array}{l}\text { Venda das } \\
10+\end{array}$ & 839,830 & $24 \%$ & - \\
\hline $\begin{array}{l}\text { \$ do Mercado } \\
\text { Global }\end{array}$ & $1.250,000$ & $100 \%$ & - & $\begin{array}{l}\text { \$ do Mercado } \\
\text { Global }\end{array}$ & $3.500,000$ & $100 \%$ & - \\
\hline
\end{tabular}

Fonte: ETC Group, 2005.

Conforme os dados da tabela 2, as dez maiores empresas que manejam nos segmentos de Produção/Comercialização/Agroindustrialização/Distribuição de 
Alimentos e Bebidas, além do segmento de Supermercados, são as principais tradings que operam no comércio mundial da compra de commodities agrícolas como arroz, leite, carnes, açúcar, agrocombustíveis, cacau, milho, soja, algodão, colza e trigo.

Ademais, são as responsáveis pela transformação destas e de outras matérias-primas (água e frutas) em produtos agroindustrializados como iogurtes, margarinas, azeites, farinhas, biscoitos, lecitina de soja, massas, leite, leite em pó, bebidas, refrigerantes, água, temperos, sorvetes, alimentos enlatados, alimentos infantis, alimentos para cães e gatos, etc. Essa grande diversidade permite as 10 principais companhias responder por cerca de 23,81\% (297,596 milhões de dólares) dos 1.250 milhões de dólares comercializados no mundo neste setor.

No geral, cada uma das 10 empresas líderes destes setores controlava de $1 \%$ a 5\% do mercado global, graças à rede de gestão articulada pelas suas filiais, subsidiárias e associadas, que "tramam" acordos, contratos e parcerias com produtores rurais integrados, cooperativas e produtores dependentes, que acatam as normativas impostas por estas empresas no processo produtivo e na qualidade dos produtos comercializados.

Além disso, as grandes cadeias de hipermercados também têm apresentado participação importante neste ramo de negócios, pois as 10 principais companhias controlam juntas por $24 \%$ (839,830 milhões de dólares) dos cerca de 3.500 milhões comercializados pelo segmento em 2004. Empresas estadunidenses (Wall-Mart, Kroger, Costco, Albertson`s); francesas (Carrefour, ITM Enterpriseres); alemãs (Metro AG, Edeka Zentrale) e dos países baixos (Ahold) têm se destacado como as principais, estendendo cadeias em diversos países e em praticamente todos os continentes.

\section{Os impactos negativos da expansão global do agronegócio.}

Segundo Antunes (2002, p. 34), desde o final da década de 1970, o capital tem vivenciado uma crise de acumulação que tem exigido sua reestruturação, processo que visa, a um só tempo, recuperar o ciclo produtivo e o processo de acumulação e controlar a conflitualidade social emergente. No campo, a reestruturação do capital se faz deteriorando as condições de vida dos agricultores menos capazes, notadamente, os camponeses. 
Para Elias (2003), a rentabilidade do capital, almejada pela economia globalizada, tornou necessária a existência de formas mais eficazes de produção, alterando a lógica de produção e as relações sociais estabelecidas na agropecuária. Neste sentido, o capital expande uma lógica destrutiva, que rompe com todas as formas de relações sociais e de produção "atrasadas".

Assim, o capital ou rompe com a agricultura camponesa tradicional, que sobrevive à margem do processo econômico global, ou exige a emergência de uma agricultura camponesa integrada, dependente e produtiva, assim como a consolidação das grandes propriedades monocultoras ligadas à produção de commodities exportáveis. Leff (2000) caracterizou a agricultura tradicional camponesa como aquela efetuada por agricultores que constroem padrões tecnológicos simples para aproveitar o potencial produtivo dos ecossistemas onde se inserem e articulam suas práticas produtivas a uma racionalidade, que mescla processos simbólicos e de significação cultural como cosmovisões, mitos e crenças religiosas, que "[...] determinam as formas técnicas, os ritmos e a intensidade da transformação da natureza, seus padrões de consumo e o acesso socialmente sancionado a seus recursos." (LEFF, 2000, p. 97). Destaca-se neste processo de organização social e produtiva as culturas camponesas tradicionais e as comunidades "primitivas".

Para Graziano da Silva (1982, p. 3), os agricultores que praticam esta agricultura assentada “[...] na relação Homem-Natureza (e suas contradições)”, o fazem motivados por certa resistência à inovação e ao risco, pois as práticas agropecuárias desses agricultores são determinadas por métodos históricos de tentativa e erro, construídas por meio da transferência e a reprodução cultural dos conhecimentos técnicos que, na sua magnitude, foram e continuam sendo a base de sua sustentação econômica e social.

Por exclusão, todo estabelecimento rural que está organizado no campo e não apresenta maximização do benefício econômico mercantil e de modernização acelerada pela incorporação de elementos técnico-científicos é tido como participante da agricultura tradicional. Porém, Schultz (1965) destaca que, no mundo todo, há uma enorme quantidade de agricultores que, durante gerações, praticam a agricultura tradicional, mas em comparação com outros segmentos de agricultura denominados 
"modernos", ainda assim, apresentam uma eficiência econômica considerável, o que coloca em xeque a discussão sobre qual agricultura é atrasada e qual é desenvolvida.

Schultz (1965) entende que isso acontece porque ainda que os agricultores tradicionais invistam menos recursos em capital, introduzem menor quantidade e qualidade em elementos técnicos (máquinas, equipamentos, insumos, etc.) e científicos (sementes, plantas e animais melhorados). Mesmo assim, uma quantidade importante destes produtores consegue obter um retorno econômico que garante a sustentação das famílias e/ou das comunidades onde vivem. Além disso, até mesmo a geração de excedentes comercializáveis, permanecendo como produtores rurais no campo. Enfim, superam os patamares de renovação.

$\mathrm{Na}$ comparação a outros modelos, a agricultura tradicional é a prática produtiva e o modelo territorialmente dominante em vários países, com alcance social nada desprezível, ainda que na literatura se teorize o contrário. Conforme Altieri (2004, p. 22),

Os sistemas de cultivo tradicionais fornecem $20 \%$ da oferta de alimentos no mundo. (...) Os policultivos constituem no mínimo de $80 \%$ da área cultivada da África Ocidental e boa parte da produção de alimentos básicos nos trópicos latino-americanos.

Ao destacar a importância da agricultura tradicional no contexto mundial e explicitar que as formas de agricultura modernas são socialmente injustas, pois resultam no processo de exclusão do campesinato, Mazoyer e Roudart (1997) afirmaram que

Apesar dos bilhões gastos para promover a agricultura 'moderna', utilizando muito capital e muito pouca mão-de-obra, que triunfou nos países desenvolvidos, apenas penetrou em alguns setores limitados dos países em vias de desenvolvimento.

A grande maioria do campesinato desses países é demasiada pobre para comprar grandes máquinas e grande quantidade de adubos.

Cerca de 80 por cento dos agricultores da África, 40 a 60 por cento destes da América Latina e da Ásia continuam a trabalhar unicamente com utensílios manuais, e somente 15 a 30 por cento de dispõem da tracção animal. A agricultura moderna está, portanto, muito longe de ter conquistado o mundo; as outras formas de agricultura permanecem predominantes e continuam a ocupar a maioria da população activa dos países em vias de desenvolvimento (MAZOYER; ROUDART, 1997, p. 12).

Interpretando a conjuntura agrária mundial, Mazoyer (2001) destaca que na base dessa desintegração do campesinato está o processo de industrialização, o modelo excludente de políticas públicas de modernização e o desigual acesso e incorporação dos avanços técnicos e científicos, já que a industrialização da agricultura asseverou as 
diferenças entre os produtores pequenos, médios e grandes e ampliou a capacidade de drenagem da renda da terra efetuada pelo capital, o que dilatou o processo de desintegração das unidades familiares de produção e a lógica de exclusão social no campo.

Por supuesto, un salto hacia adelante de esta envergadura no tuvo lugar de una sola vez, sino por etapas, ni tampoco ocurrió en todas las explotaciones agrícolas, si no en una minoría, cada vez menos numerosa, mientras que la gran mayoría de las explotaciones existentes a principios de siglo iban desapareciendo unas tras otras (MAZOYER, 2001, p. 10).

Para o autor, efetivamente, pouco a pouco tem sido destruídos, em nível mundial, os estabelecimentos rurais situados em regiões menos favoráveis em clima, solo e localização. Já os estabelecimentos suficientemente bem equipados e dimensionados para alcançar bons índices de produtividade, as médias e as grandes propriedades, puderam se desenvolver e continuar produzindo no campo, pois conseguiram obter uma renda superior às necessidades da família dos agricultores, que consegue cobrir os custos de produção, pagar as dívidas e reinvestir na produção.

$\mathrm{Na}$ escala global, poucos produtores foram efetivamente beneficiados pelas condicionantes da industrialização, já que o apoio público e as vantagens econômicas garantidas pelo Estado (financiamentos, subsídios, etc.) foram parciais. Com efeito, somente uma ínfima fração dos produtores conseguiu incorporar em seus estabelecimentos os elementos técnicos e científicos direcionados ao aumento da produção agropecuária, tornando-se produtores rurais mais dinâmicos, ampliando sua capacidade de produção e de produtividade, enfim, ultrapassando o limiar de resistência às crises agrícolas e de continuar sobrevivendo e produzindo no espaço agrário.

Segundo os estudos de Mazoyer (2001) e Mazoyer e Roudart (1997), o estado de pobreza e de exclusão social de parte considerável dos agricultores aconteceu porque somente um terço dos cerca de 1,3 bilhões de agricultores existentes no mundo foram afetados positivamente pelo processo de industrialização agropecuária no contexto da "Revolução Verde".

Assim, enquanto 33\% dos agricultores puderam comprar os insumos, as máquinas agrícolas e as sementes necessárias para aumentar a sua capacidade produtiva, $66 \%$ dos produtores restantes tiveram somente a alternativa de continuar produzindo, de maneira artesanal, com resistência à pressão exercida pela concorrência desleal dos 
produtores equipados e às proteções artificiais decorrentes dos subsídios agrícolas e das políticas de proteção estipuladas pelos países mais ricos ou por seus próprios governantes.

No caso específico da motomecanização, somente $2 \%$ dos agricultores - algo em torno de 26.000.000 de agricultores - puderam se equipar e adquirir ao menos um dos cerca de 28 milhões de tratores existentes no mundo.

Esto quiere decir que la gran motorización y la mecanización compleja que, junto con las variedades de plantas y las razas de animales seleccionados, los fertilizantes, los alimentos concentrados, y los productos de tratamiento de las plantas y de los animales, constituyen la punta de lanza de la revolución agrícola contemporánea, no han beneficiado más que a una ínfima minoría de los agricultores del mundo (en este texto, los términos agricultores, cultivadores de cereales y de otros productos y campesinos se refieren tanto a hombres como a mujeres (MAZOYER, 2001, p. 02).

Para Mazoyer (2001), esta característica de desenvolvimento foi muito desigual, pois garantiu a evolução econômica de poucos produtores e significou o bloqueio econômico, a crise e a exclusão social para muitos. No plano internacional, a comparação entre os países ricos e pobres revelou que esta diferenciação foi ainda mais "gritante".

Por otra parte, las explotaciones campesinas menos equipadas, de menores dimensiones, y a menudo peor situadas y menos productivas, cuyos ingresos familiares eran inferiores a un umbral de renovación, es decir al umbral de ingresos socialmente aceptable, cercano al salario mínimo del momento, no podían ni invertir, ni ampliarse, ni siquiera renovar plenamente sus medios de producción. De hecho, estas explotaciones, que tendían a descapitalizarse y a retroceder, eran abandonadas en general cuando el explotador se jubilaba, estaban en crisis y en vías de desaparición (MAZOYER, 2001, p. 10).

Ainda segundo Mazoyer (2001), a industrialização efetiva da agricultura ocorreu em seletos países nas diversas regiões do mundo, visto que triunfou nas economias capitalistas desenvolvidas e debilmente se afirmou nas economias capitalistas subdesenvolvidas.

Esta difusão internacional do processo de industrialização asseverou ainda mais a diferenciação social entre os agricultores, já que poucos foram favorecidos; muitos desapareceram, pois perderam suas terras; e uma quantidade também grande continuou sobrevivendo no campo, porém de maneira cada vez mais marginal, já que os índices de pobreza e de fome no campo revelam a existência efetiva de milhares de pessoas pobres e sem condição de produzir ao menos sua alimentação básica. 
Conforme as interpretações de Mazoyer (2001) e Amin (2004), somente uma pequena parcela dos camponeses e dos médios produtores rurais - proprietários de terra ou não - mas, sobretudo, a grande maioria dos grandes produtores rurais do Cone Sul da América Latina (Argentina, Chile, Brasil, Paraguai e Uruguai); da Ásia (Vietnã, Malásia, Tailândia, países do Oriente Médio como Síria, Irã) e África (África do Sul e países situados no norte da África, como o Marrocos) puderam se equipar, adquirindo, por meio de políticas públicas destinadas à industrialização da agricultura, os tratores, máquinas agrícolas, implementos e insumos modernos que possibilitaram ampliar sua capacidade laborativa, produtividade, produção e renda.

De acordo com Amin (2004), nestas regiões e países, destacam-se dois setores: o segmento da "[...] agricultura capitalista governada pelo princípio de retorno sobre o capital" (AMIN, 2004, p. 74), praticado em médias e grandes fazendas, onde cada proprietário produz anualmente em torno de 1.000 a 2.000 toneladas de grãos por ano; e o segmento camponês modernizado, que obtém de 10 a 50 toneladas de grãos por ano.

Contudo, para a maioria dos produtores camponeses dos países supracitados e para a totalidade dos produtores camponeses de nações onde o processo de industrialização foi pouco efetivo ou simplesmente nulo (centro da África e África SubSahariana, Andes americanos, uma série de países da Ásia), o processo de industrialização não ocorreu. À margem do processo, o empobrecimento e a exclusão do campesinato se tornaram a tônica nestas sociedades.

\begin{abstract}
A final de cuentas, queda más o menos, un tercio de los agricultores del mundo a los que no ha llegado ni la revolución agrícola, ni la revolución verde, ni la tracción animal: sólo disponen de unos aperos estrictamente manuales $\mathrm{y}$, sin fertilizantes ni productos de tratamiento, cultivan o crían variedades o razas que no han sido objeto de ninguna selección. Una agricultura rural pobre, carente de todo tipo de investigación y de todo proyecto, que cuenta aproximadamente con 450 millones de trabajadores, es decir, 1250 millones de personas que viven mal o muy mal de la agricultura. Estos agricultores no pueden superar una productividad bruta de 1 tonelada de grano por trabajador y por año (1 ha/trabajador/año x $1 \mathrm{t} / \mathrm{ha}$ en secano, ó 0,5 ha/trabajador x 2 t/ha en regadío). (MAZOYER, 2001, p. 02).
\end{abstract}

Assim, as inovações tecnológicas introduzidas na agricultura, pouco a pouco, engendraram um mecanismo de destruição do trabalho vivo, inerente às formas artesanais camponesas nos lugares e regiões onde ocorriam, em favor de padrões de agricultura assentados nos grandes estabelecimentos rurais, produtores de agricultura extensiva, direcionados à exportação, capital-intensivas no uso de maquinaria, insumos 
(semente, adubos, pesticidas agrícolas) e, sobretudo, baseados no assalariamento.

De posse das informações censitárias e estatísticas sócio produtivas dos países que analisou e corroborado pelas leituras teóricas dos autores aos quais se referiu, Abramovay (1992) afirma que a partir do momento em que agentes econômicos do capital nacional e internacional se territorializaram, na escala local e regional, provocaram uma reestruturação econômica profunda, modernizando as relações socioeconômicas a tal ponto que desregularam o micro-cosmo da economia local regional e as "engrenagens" dos mercados ditos incompletos, destruindo, conseqüentemente, as bases de sustentação e de funcionamento da economia camponesa.

\begin{abstract}
As sociedades camponesas são incompatíveis com o ambiente econômico onde imperam relações claramente mercantis. Tão logo os mecanismos de preços adquiram a função de arbitrar as decisões referentes à produção, de funcionar como princípio alocativo do trabalho social, a reciprocidade e a personalização dos laços sociais perderão inteiramente o lugar, levando consigo o próprio caráter camponês da organização social (ABRAMOVAY, 1992, p. 117).
\end{abstract}

Segundo Abramovay, estas transformações, no seio do campesinato tradicional, redundariam tanto no fim do campesinato pela sua exclusão, quanto no surgimento dos Agricultores Familiares, um extrato do processo capitalista de produção agrícola, que mesmo detendo reduzida dimensão agrícola para explorar, controlaria um aparato técnico-produtivo ímpar que o qualificaria a participar em redes e cadeias produtivas capitalistas muito específicas e sob o aparato de distintas políticas públicas de fomento, de forma que estes agricultores conseguiriam obter altos índices de produtividade e de renda.

No entendimento de Amin (1986), esta forma de desenvolvimento capitalista promoveria a proletarização do campesinato, ainda que dissimulada, porque, do ponto de vista formal, apesar de os camponeses deterem a terra e os meios de produção, quem dita as regras e os ritmos do processo produtivo e fica com a maior parte do lucro são os agentes do capital, os líderes do agronegócio.

O capital dominante anula a renda, livra-se da propriedade fundiária e proletariza o camponês trabalhador (...) que conserva a propriedade formal da terra, mas não tem mais a propriedade real. Conserva, também, a aparência de um produtor comerciante que oferece produtos no mercado, mas na verdade é um vendedor de força de trabalho, e sua venda é disfarçada pela 
aparência de produção comercial. Assim o camponês é reduzido, de fato, à condição de trabalhador a domicílio. (AMIN, 1986, p. 29).

Fato é que todo este emaranhado de situações se insere no processo geral de desenvolvimento "sóciometabólico do capital" (MÉSZÁROS, 2002, p. 42), cujo ímpeto e força de destruição e recriação moldam, por meio de variados mecanismos de controle, as diversas manifestações socioeconômicas, a fim de garantir ao capital a sua viabilidade (re)produtiva, que se assenta na construção de uma realidade hierárquica de controle sobre o trabalho em suas diversas manifestações, garantindo a extração continuada e ampliada da riqueza que emana do trabalho.

\begin{abstract}
Não se pode pensar um sistema de controle mais inexoravelmente absorvente - e, neste importante sentido, "totalitário" - do que o sistema do capital globalmente dominante, que sujeita cegamente aos mesmos imperativos a questão da saúde e a do comércio, a educação e a agricultura, a arte a indústria manufatureira, que implacavelmente sobrepõe a tudo seus próprios critérios de viabilidade, desde as menores unidades de seu "microcosmo" até as mais gigantescas empresas transnacionais, desde as mais íntimas relações pessoais aos mais complexos processos de tomada de decisão dos vastos monopólios industriais, sempre a favor dos fortes e contra os fracos (MÉSZÁROS, 2002, p.96).
\end{abstract}

De fato, ao "varrer" do campo o camponês tradicional, incorporando alguns em sua lógica de acumulação ampliada ou relegando em algum momento os "eleitos" ao abandono, a reestruturação produtiva do capital visa asseverar, ainda mais, as contradições e a necessidade de superar as formas de realização do trabalho assentadas na pequena propriedade de caráter familiar. Para tanto, o capital cria mecanismos para ampliar a apropriação e a subordinação das diferentes formas de trabalho à sua lógica, seja incorporando a propriedade privada, seja estruturando novos mecanismos de drenagem da renda e apropriação do trabalho social de produtores individuais, coletivos e de trabalhadores assalariados.

Nesta lógica, nem mesmo os camponeses integrados e funcionais ao sistema têm a sua manutenção social assegurada. Um dos mecanismos centrais é impor integrações horizontais e cadeias produtivas cada vez mais complexas, com novas regras, ritmos produtivos, qualificações, especificações, em dimensões e com inovações tais que os produtores que não se "encaixam" no padrão são efetivamente afastados, rompendo-se os contratos de integração.

Outra "sacada" do capital é cobrar do poder público investimentos que favoreçam a implementação desta lógica. São notórias, em nível mundial, as políticas 
públicas de apoio e financiamento a agricultores. Estes absorvem investimentos e direcionam seus estabelecimentos à produção agropecuária em segmentos específicos (cana-de-açúcar e outros biocombustíveis como as oleaginosas dendê, mamona, pinhãomanso, além de cultivos como soja, beterraba, leite, pinnus e eucalipto, milho, granjeiros, etc.). Por meio desses recursos, os agricultores, na verdade, beneficiam as agroindustriais e as cadeias comerciais e industriais a montante e a jusante.

Esta busca pela excelência produtiva, com a produção a menor custo para o capital, por sua vez, gera uma situação de desequilíbrio internacional, já que a comercialização da produção é realizada em escalas cada vez maiores. Os países mais afetados são aqueles que apresentam produtores menos equipados, relegados pelas políticas públicas e que dependem basicamente da agricultura para sobreviver. Possuindo menor produtividade, conseqüentemente, os produtores desses países são impactados negativamente em razão da dominação do mercado pelas multinacionais, que desregulam os mercados locais/regionais provocando o empobrecimento e a exclusão dos agricultores pobres.

É importante esclarecer que as revoluções tecnológicas incorporadas na agricultura permitiram aumentar, de maneira gradual e constante, a oferta de alimentos, suplantando o crescimento populacional e os riscos de falta de alimentos alardeados em meados do século passado (tabela 3).

Tabela 3: Indicadores da evolução populacional e da produção agrícola mundial entre 1975 e 2005.

\begin{tabular}{lrrr}
\hline Indicadores & $\mathbf{1 9 7 5}$ & $\mathbf{2 0 0 5}$ & Variação (\%) \\
\hline População total (milhões) & 3.693 & 6.453 & 74,74 \\
Produção (milhões de toneladas) & 1.225 & $2.219,4$ & 81,18 \\
Área cultivada (milhões de hectares) & 695 & 681,7 & $-1,91$ \\
Produtividade média (mil kg/hectare) & 1,76 & 3,26 & 84,71 \\
Oferta per capita anual (kg) & 310,00 & 340,00 & 9,68 \\
\hline
\end{tabular}

Fonte: FAO, 2006.

Ademais, nos seguimentos alimentares das carnes (frango, suínos e bovinos), do milho, do arroz, do trigo, do feijão, do leite e de produtos agroindustriais específicos como a soja, também houve uma considerável tendência de crescimento da produção, conforme tabela 4. 
Tabela 4: Produção agrícola mundial de produtos específicos entre 1961 e 2005 (em toneladas).

\begin{tabular}{|c|c|c|c|c|c|c|c|}
\hline Produto & 1961 & 1970 & 1980 & 1990 & 2000 & 2005 & Var. \% 1961/2005 \\
\hline Soja & 26.882 .808 & 43.696 .887 & 81.039 .568 & 108.453 .156 & 161.406 .339 & 214.347 .289 & $697,3 \%$ \\
\hline Carnes & 71.343 .133 & 100.623 .729 & 136.678 .927 & 179.939 .905 & 235.096 .410 & 265.428 .707 & $272,0 \%$ \\
\hline Milho & 205.004 .683 & 265.831 .145 & 396.623 .388 & 483.336 .300 & 592.790 .116 & 701.666 .160 & $242,3 \%$ \\
\hline Arroz & 215.654 .697 & 316.384 .298 & 396.871 .255 & 518.229 .077 & 599.097 .676 & 618.440 .644 & $186,8 \%$ \\
\hline Trigo & 222.357 .231 & 310.741 .644 & 440.204 .101 & 592.309 .008 & 586.059 .624 & 629.566 .041 & $183,1 \%$ \\
\hline $\begin{array}{l}\text { Leite } \\
\text { (mil litros) }\end{array}$ & 344.185 .940 & 391.758 .948 & 465.559 .150 & 542.533 .887 & 579.614 .725 & 629.101 .719 & $82,8 \%$ \\
\hline Feijão & 11.228 .313 & 12.629 .727 & 13.711 .771 & 17.449.341 & 16.859 .908 & 18.747 .741 & $67,0 \%$ \\
\hline
\end{tabular}

Fonte: FAO, 2006.

Como pode ser visualizado na tabela 4, apesar dos índices de crescimento da produção de leite $(82,8 \%)$ e de feijão $(67 \%)$ terem superado o índice de crescimento da população $(74,74 \%)$, apresentado na tabela 3 , mundialmente, observou-se $o$ crescimento considerável da produção de trigo $(183,1 \%)$ e de arroz $(186,8 \%)$, que praticamente dobrou no período. Seguindo esta tendência, houve aumento considerável da produção de milho (242,3 \%) e de carnes (272\%), refletindo, portanto, numa maior quantidade de alimentos básicos disponíveis no mundo.

Apesar do aumento da produção agrícola mundial, dados da FAO (2002, p. 21) revelam que, adentrando o século XXI, mais de 2,1 bilhões de pessoas vivem com menos de 2 dólares estadunidenses por dia, e cerca da metade deste número (1,1 bilhões de pessoas) vivem em estado de extrema pobreza, subsistindo com menos de 1 dólar por dia, situação calamitosa.

Além disso, a FAO (2002) destaca que sete em cada dez pobres do mundo habitam zonas rurais, e que a maioria dos pobres do campo é “[...] pequeños proprietários, campesinos sin tierras, pastores tradicionales, pescadores artesanos y grupos marginales como refugiados, poblaciones indígenas y hogares encabezados por una mujer" (FAO, 2002, p. 88); destacando as diferentes classes (pequenos, médios e grandes produtores) e a questão de gênero relacionada ao campesinato pobre. Porém, a face mais grave da pobreza mundial é a fome. 
Cerca de 800 millones de personas - una sexta parte de la población del mundo en desarrollo - no tienen acceso a suficiente comida para llevar una vida saludable y productiva. Aproximadamente 280 millones de estos alimentariamente inseguros viven en el Sur de Asia; 240 millones en el Este de Asia; 180 millones en el África del Sub-Sahara y el resto (100 millones) en Latinoamérica, el Medio Oriente y el Norte de Africa. Aunque se ha progresado en el combate de la inseguridad alimentaria, el avance es lento (FAO, 2002, p. 113).

Como se explica, então, a existência da fome, se a cada ano que passa aumenta a produção e a produtividade na agricultura? Analisando esta questão, interpreta-se que o problema da fome tem três causas centrais: a) acesso ao alimento, questão relacionada à falta de recursos da população urbana para comprar os alimentos; b) dificuldade dos camponeses pobres colocarem em produção suas terras, já que estão desassistidos das políticas públicas; c) o modelo agrícola estruturado pelo Agronegócio que, se não exclui parte dos produtores pelos mecanismos de concentração fundiária e pelos mecanismos de baixos salários, o faz pelos mecanismos de mercado, uma vez que é uma prática corrente a drenagem da renda dos produtores rurais, fato que gera desestímulo e pobreza no campo e um encarecimento dos preços dos alimentos aos consumidores em geral.

Ademais, a lógica do mercado é valorizar e investir em setores com maior perspectiva de retorno, como a produção de grãos ligados à cadeia de processamento agroindustrial e com preços regulados em bolsa de valores, como é o caso da soja, a vedete do mercado global de grãos. Como se sabe, a soja não é consumida in natura, mas sim na forma de sub-produtos (lecitina, proteína e extrato de soja) que compõem alimentos industrializados diversos (pães, bolos, massas, bebidas, iogurtes, chocolates, etc.).

Como são as megaempresas que coordenam o Agronegócio na escala global, a força econômica acumulada e a habilidade operacional destas organizações ampliam também não só suas capacidades territoriais, mas também a potencialidade de seus impactos negativos, à medida que as estratégias de ampliação da rentabilidade dos negócios se estabelecem no agro setor.

A concentração multinacional nos principais setores ligados à agricultura tem dotado as principais companhias de um poder sem precedentes para arquitetar as políticas sociais, econômicas e comerciais. Em virtude disso, essas empresas podem "jogar duro" na defesa de seus interesses, seja em um país, seja na escala local e 
regional, onde realiza as compras de matérias-primas, seja na escala global e no contexto do mercado internacional, onde realiza suas vendas.

\begin{abstract}
A ideia de que a produção agropecuária tem que servir o mercado é difundida pelas transnacionais agro-químico-alimentares, exatamente para manterem seu controle direto e decisório não somente as relações de troca, mas toda a cadeia produtiva dos alimentos, a qual inclui a produção imediata, a circulação, o consumo e, em decorrência, expressivas parcelas da classe trabalhadora, desde os campos até os diversos setores urbanos do processamento agroindustrial. (THOMAZ JÚNIOR, 2007, p. 10).
\end{abstract}

Uma das principais estratégias é a concentração do capital, via incorporações (compra das empresas concorrentes), ou mesmo a conquista de contratos de exclusividade na oferta de produtos entre empresas que vendem matérias-primas com as que industrializam a produção, ou entre agroindústrias processadoras e distribuidoras. Se por um lado, esses tipos de acordo facilitam a defesa dos interesses das "gigantes" de cada setor, por outro, fragilizam ainda mais os produtores rurais das nações menos desenvolvidas, em cujas economias o setor agrícola é o mais importante.

As normativas estipuladas de cima para baixo exigem processos produtivos mais rígidos e custos mais baixos, forçando os produtores: a intensificarem os investimentos tecnológicos para garantir aumento de produção e produtividade em ambiente de negócios de menores lucros; e a fecharem contratos de integração desfavoráveis, já que o preço da matéria-prima pago pela contratante tende a ser mais baixo e os riscos operacionais ao produtor ainda mais elevados.

Também é evidente o problema alimentar que afeta os consumidores e a ocorrência de fatos bastante peculiares que compõem o DNA do sistema agrícola e alimentar contemporâneo, propugnado pelo agronegócio: preços baixos das matériasprimas agrícolas versus preços muito altos dos produtos disponibilizados aos consumidores; aumento exponencial da fome, seja no campo ou na cidade; quantidade cada vez maior de pessoas obesas e subalimentadas, pois os alimentos tendem a ser menos nutritivos, apesar que são muito atraentes dada as estratégias de marketing entorno da quantidade de produtos, expostos nas prateleiras dos supermercados, que abastecem os centros urbanos; além de gravíssimos problemas ambientais (erosão, 


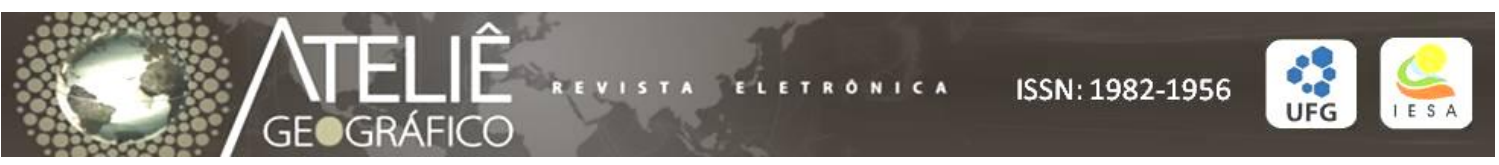

poluição, desperdício de água, desmatamento, erosão genética via destruição de biomas, expansão dos transgênicos, etc.).

\title{
Considerações Finais.
}

Os problemas da exclusão social do campesinato e a questão da fome no campo e na cidade só serão superados mediante uma reorganização do sistema produtivo não mais em razão das necessidades de acumulação de capital em escala global, mas cada vez mais focadas no desenvolvimento local e sustentável.

Em outras palavras, a solução está na própria superação do Agronegócio e a emergência de formas de produção ecologicamente sustentáveis, socialmente mais justas, entre as quais a Agroecologia, sobretudo, coordenada pelos pequenos e médios produtores rurais.

\begin{abstract}
A despeito de seus sucessos, contudo, nosso sistema de produção global de alimentos está no processo de minar a própria fundação sobre a qual foi construído. As técnicas, inovações, práticas e políticas que permitiram aumentos na produtividade também minaram a sua base. Elas retiraram excessivamente e degradaram os recursos naturais dos quais a agricultura depende - o solo, reservas de água e a diversidade genética natural. Também criaram dependência de combustíveis fósseis não renováveis e ajudaram a forjar um sistema que cada vez mais retira a responsabilidade de cultivar alimentos das mãos de produtores e assalariados agrícolas, que estão na melhor posição para serem os guardiões da terra agriculturável. Em resumo, a agricultura moderna é insustentável - ela não pode continuar a produzir comida suficiente para a população global, a longo prazo, porque deteriora as condições que a tornam possível (GLIESSMAN, 2001, p. 33).
\end{abstract}

Dessa forma, em longo prazo, há a necessidade de reestruturação nas práticas agrícolas para garantir a produção de alimentos, com a emergência de sistemas produtivos menos dependentes de insumos externos e que se baseiem em tecnologias que incorporem o legado dos conhecimentos tradicionais desenvolvidos pelas comunidades camponesas. Essa mudança de perspectiva poderá dinamizar a produção de alimentos principalmente em regiões onde o problema da fome é mais grave (América Latina, África e Ásia).

O desafio colocado é o de potencializar estratégias de manejo dos recursos naturais e dos fatores de produção que ampliem a participação dos agricultores mais pobres, sem, no entanto, negar sua possibilidade de desenvolvimento. Fato que não ocorreu ao longo das últimas décadas, quando o desenvolvimento da agricultura foi pensado por meio de tecnologias caras e excludentes, focado nos interesses dos megaconglomerados econômicos ligados ao Agronegócio.

\section{Referências Bibliográficas.}


ABRAMOVAY, Ricardo. Paradigmas do capitalismo agrário em questão. São Paulo/Campinas: Hucitec/Editora da Unicamp,1992.

ALTIERI, Miguel, Agroecologia - A dinâmica produtiva da agricultura sustentável. Porto Alegre: Editora da UFRGS, 2004.

AMIN, Samir. A crise do capitalismo e a vitimização camponesa. In: VIA CAMPESINA BRASIL. A situação internacional da agricultura. São Paulo: Via Campesina, 2004.

AMIN, Samir. O capitalismo e a renda fundiária (A dominação do capitalismo sobre a agricultura). In: AMIN, Samir.; VERGOPOULOS, K.ostas A questão agrária e o capitalismo. Rio de Janeiro: Paz e Terra, 1986.

BRUM, Argemiro Jacob. Modernização da agricultura. Petrópolis: Vozes, 1988.

CAPRA, Fritjof. As conexões ocultas. Ciência para uma vida sustentável. São Paulo: Pensamento-Cutrix, 2005.

CASTRO, Ana Célia. SILVEIRIA, José Maria F. J. da. Inovações biológicas para a agricultura: da via híbrida à engenharia genética. In: MARTINE, George e CASTO, Cláudio de M. Biotecnologia e Sociedade: o caso brasileiro. Campinas: Editora da Unicamp; são Paulo: ALMED, 1985.

ELIAS, Denise. Globalização e agricultura. São Paulo: Edusp, 2003.

ETC GROUP. Oligopólio, S.A. Concentración del poder corporativo. Ottawa: ETC Goup: Comuniqué. $\mathrm{N}^{\circ}$ 91, nov/dez, 2005. Disponível em:

www.etcgroup.or/upload/publication/pdf_file/43. Acesso em: março 2008.

FAO. Agricultura Mundial: hacia los años 2015/2030. Roma: Organización de las Naciones Unidas para la Agricultura y la Alimentación, 2002.

FAO. El estado Mundial de la Agricultura y la Alimentación 2005. Roma:

Organización de las Naciones Unidas para la Agricultura y la Alimentación, 2006.

GLIESSMAN, Stephen R. Agroecologia: processos ecológicos em agricultura sustentável. 2.ed. Porto Alegre: Ed. Universidade/UFRGS, 2001.

GRAZIANO DA SILVA, José. A modernização dolorosa: estrutura agrária, fronteira agrícola e trabalhadores rurais no Brasil. Rio de Janeiro: Zahar, 1982.

KAUTSKY, Karl. A questão Agrária. São Paulo: Nova Cultural, 1986.

LEFF, Henrique. Ecologia, capital e Cultura. Racionalidade ambiental, democracia participativa e desenvolvimento sustentável. Blumenau: Edfurb, 2000. 
LÊNIN, Vladimir Ilitch. O desenvolvimento do capitalismo na Rússia. São Paulo: Abril Cultural, 1982.

MAZOYER, Marcel. Defendiendo al campesinado en un contexto de globalizacion. Roma: FAO, 2001.

MAZOYER, Marcel. ROUDART, Laurence. História das Agriculturas do Mundo: do Neolítico à crise contemporânea. Lisboa: Piaget, 1997.

MÉSZÁROS, Istivan. Para além do capital. São Paulo: Boitempo, 2002.

SANTOS, Milton. Por uma outra globalização. Do pensamento único à consciência universal. Rio de Janeiro: Record, 2002.

SCHULTZ, Theodore W. A transformação da agricultura tradicional. Rio de Janeiro: Zahar, 1965.

THOMAZ JÚNIOR, Antônio. Trabalho mutante e território em disputa. Presidente Prudente: mimeo, 2007.

Recebido para publicação em março de 2011 Aprovado para publicação abril de 2011 